\title{
Inside the small-scale composting of kitchen and garden wastes: Thermal performance and stratification effect in vertical compost bins
}

\author{
Juan Pablo Arrigoni ${ }^{\mathrm{a}, *}$, Gabriela Paladino ${ }^{\mathrm{a}}$, Lucas Garibaldi ${ }^{\mathrm{a}, \mathrm{b}}$, Francisca Laos ${ }^{\mathrm{a}}$ \\ ${ }^{a}$ Instituto de Investigaciones en Recursos Naturales, Agroecología y Desarrollo Rural (IRNAD) - Universidad Nacional de Río Negro, Sede Andina, Av. Bustillo No 1500, Bariloche \\ (8400), Rio Negro, Argentina \\ ${ }^{\mathrm{b}}$ Consejo Nacional de Investigaciones Científicas y Técnicas (CONICET), Argentina
}

\section{A R T I C L E I N F O}

\section{Article history:}

Received 30 October 2017

Revised 11 February 2018

Accepted 6 March 2018

Available online $\mathrm{xxxx}$

\section{Keywords:}

Home composting

Community composting

Compost stability

Municipal solid waste

Waste prevention

\begin{abstract}
A B S T R A C T
Decentralized composting has been proposed as a best available practice, with a highly positive impact on municipal solid wastes management plans. However, in cold climates, decentralized small-scale composting performance to reach thermophilic temperatures (required for the product sanitization) could be poor, due to a lack of critical mass to retain heat. In addition, in these systems the composting process is usually disturbed when new portions of fresh organic waste are combined with previous batches. This causes modifications in the well-known composting evolution pattern. The objective of this work was to improve the understanding of these technical aspects through a real-scale decentralized composting experience carried out under cold climate conditions, in order to assess sanitization performance and to study the effects of fresh feedstock additions in the process evolution.

Kitchen and garden organic wastes were composted in 500 L-static compost bins (without turning) for 244 days under cold climate conditions (Bariloche, NW Patagonia, Argentina), using pine wood shavings in a ratio of $1.5: 1 \mathrm{v}: \mathrm{v}$ (waste: bulking agent). Temperature profile, stability indicators (microbial activity, carbon and nitrogen contents and ratio) and other variables ( $\mathrm{pH}$ and electrical conductivity), were monitored throughout the experience.

Our results indicate that small-scale composting (average generation rate of $7 \mathrm{~kg} \mathrm{~d}^{-1}$ ) is viable under cold weather conditions, since thermophilic sanitization temperatures $\left(>55^{\circ} \mathrm{C}\right.$ ) were maintained for 3 consecutive days in most of the composting mass, according to available USEPA regulations commonly used as a reference for pathogens control in sewage sludge. On the other hand, stability indicators showed a differentiated organic matter degradation process along the compost bins height. Particularly, in the bottommost composting mix layer the process took a longer period to achieve compost stability than the upper layers, suggesting that differential organic matter transformation appears not to be necessarily associated to the order of the waste batches incorporation in a time line, as it could be expected. These findings suggest the need to discuss new ways of studying the composting process in small-scale compost bins as well as their commercial design.
\end{abstract}

(c) 2018 Elsevier Ltd. All rights reserved.

\footnotetext{
Abbreviations: EC, electrical conductivity; LSD, least significant difference; m.a.s. 1., meters above the sea level; MSW, municipal solid wastes; NW, Northwest; OM, organic matter; PC, principal component; PCA, principal component analysis; PFRPs, process to further reduce pathogens; TKN, total Kjeldahl nitrogen; TOC, total organic carbon; USEPA, United States Environmental Protection Agency; WSC, water-soluble carbon.

* Corresponding author.

E-mail addresses: jparrigoni@unrn.edu.ar (J.P. Arrigoni), gpaladino@unrn.edu.ar (G. Paladino), lgaribaldi@unrn.edu.ar (L. Garibaldi), francis.laos@gmail.com (F. Laos).
}

\section{Introduction}

Decentralized or small-scale composting is an effective tool to treat the organic fraction of municipal solid wastes (MSW) and has been proposed as a best available practice with a highly positive impact on MSW management plans. This technology contributes to reducing waste transportation, treatment costs and landfilling volumes, as it was demonstrated in several life cycle assessments reported in literature (Chan et al., 2011; Colón et al., 2010; Lleó et al., 2013). Decentralized composting has been successfully implemented for kitchen and garden organic wastes treatment in institutions, neighborhoods and homes, at low costs 
(Platt et al., 2014; Smith and Jasim, 2009). Thus, this system represents an attractive technology alternative for the municipal organic waste fraction treatment in various socio-economic and technological contexts (Kalamdhad and Kazmi, 2009a; Kalamdhad and Kazmi, 2009b). Furthermore, small-scale composting is also an innovative way to involve generators as a key factor in their own waste treatment, raising community environmental awareness (Adhikari et al., 2010; Faverial and Sierra, 2014).

Nevertheless, small-scale composting frequently presents a poor performance at reaching the thermophilic temperatures recommended by the United States Environmental Protection Agency (USEPA) standard for the product sanitization of sewage sludge, known as "Process to Further Reduce Pathogens" or "PFRPs" (Abdullah et al., 2013; Barrena et al., 2014; Benjawan et al., 2015; Sánchez et al., 2015; USEPA, 2003). This may generate mistrust in technicians, public officials and common users who wish to promote decentralized composting of organic wastes, particularly in adverse (cold) weather conditions.

Composting temperature, among other physical, chemical and operational aspects, has a fundamental role in "cleaning" composting materials, since high temperatures aids in destroying pathogenic microorganisms, minimizing the attraction of vectors and helping to eliminate unpleasant odours and weed seeds viability (Diaz et al., 2007; Onwosi et al., 2017; USEPA, 2003). In sewage sludge composting in closed containers (in-vessel composting), the PFRPs standard requires to maintain the temperature above $55^{\circ} \mathrm{C}$ for three consecutive days throughout the composting matrix, for the material sanitization and a suitable process performance. Nevertheless, the temperature evolution has been extensively studied and employed for regulating the composting process of sewage sludge, but not for kitchen and garden wastes, and much less at small-scale composting.

Since commercial compost bins volume usually range from 40 to $500 \mathrm{~L}$, in these systems the thermal inertia is usually lower because the composting mass could not be enough to retain the metabolic heat generated during the composting active phase. Therefore, small-scale composting systems could have a poor performance in achieving USEPA PFRPs or other temperature sanitization standards or recommendations (Abdullah et al., 2013; Arrigoni et al., 2015; Benjawan et al., 2015; Iyengar and Bhave, 2006; Sánchez et al., 2015). In tropical and favourable climatic conditions or in controlled laboratory settings, small-scale composting has shown good temperature evolution performances (Barrena et al., 2014; Faverial and Sierra, 2014; Lleó et al., 2013; Varma and Kalamdhad, 2014). However, in cold climates, such as the Andean Patagonia region in Argentina, typical low ambient temperatures could maximize heat loss and restrict microbial activity, negatively affecting compost stabilization and sanitization, and also increasing the time required for the process to be completed (Arrigoni et al., 2015; Laos et al., 2002).

On the other hand, in a large-scale or centralized composting processes, the temperature profile as well as the evolution pattern of stability and maturity variables and indicators, are well-known. However, these parameters behaviour could be quite different in small-scale composting, and it has not been fully understood yet. Compost bins without a homogenization mechanism are the simplest, common and more promoted small-scale composting devices (Smith and Jasim, 2009; Storino et al., 2016a, 2016b). In these composters, the process usually starts when the first of various batches of organic waste is incorporated through an opening at top of the device, and it would end when the final product can be collected from a door usually placed in the bottom part of the composter. This implies that the organic matter transformation would occur according to the order of the waste portions incorporations. Thus, the first batch of waste that was incorporated would have a higher stability degree than the subsequent ones.
In this way, in small-scale systems the composting process is altered when another portion of fresh waste is combined with the material that is already being transformed. This probably causes modifications in the typical evolution of the process, further studied in centralized composting systems, generating a differentiated process evolution or a "stratification" in the organic matter transformation in a vertical direction. These modifications would be mainly related to the increase of easily degradable carbon with each fresh feedstock incorporation, and with changes in the moisture and oxygenation conditions of the composting mixture throughout the device (Iyengar and Bhave, 2006; Karnchanawong and Suriyanon, 2011; Smith and Jasim, 2009).

With the aim to contribute to small-scale composting understanding, for the technology optimization and development (particularly in cold climates), the objective of this work was twofold: (i) to assess the temperature evolution and product sanitization performance in a decentralized composting experience carried out in NW Patagonia in Argentina; (ii) to study the "stratification effect" or differentiated evolution of the composting process at the different heights (or layers) of low complexity vertical and static (without homogenization mechanism or turning) compost bins, according to standard compost stabilization indicators.

\section{Material and methods}

\subsection{Composters prototypes and experimental design}

A small-scale composting experiment was carried out outdoors in San Carlos de Bariloche $\left(41^{\circ} 07^{\prime} \mathrm{S} ; 71^{\circ} 19^{\prime} \mathrm{O}\right)$, a city located in NW Patagonia (Argentina), about 890 m.a.s.l. This city is characterized by a cold-temperate climate with a dry season (summer). The average annual temperature is $8.4^{\circ} \mathrm{C}$ and the annual rainfall average is close to $1000 \mathrm{~mm}$, normally concentrated in autumn and winter seasons.

The composter prototype designed for this experience was constructed with recycled plastic tables that were assembled in a cylindrical shape, with a plastic support base. A circular lid was added to prevent access of rainwater or snow, animals and vectors (Fig. 1a). Also, two "perimeter doors" were placed at the bottom part of the device for compost extraction. The overall dimensions of the composter were: (i) total height: $120 \mathrm{~cm}$ (effective operational height: $100 \mathrm{~cm}$ ), (ii) inner diameter: $80 \mathrm{~cm}$; (iii) effective volume for waste treatment: $500 \mathrm{~L}$. To allow leachates separation, a plastic plate was perforated with 20 holes of $2 \mathrm{~cm}$ diameter each and placed $20 \mathrm{~cm}$ up from the cylinder bottom. Between the perforated plate and the cylinder base, it was placed a tap for leachates collection. In this study, three of these composter prototypes were used (Fig. 1c).

The experience replicated the real operating conditions for a pilot case of composting in an institutional catering service. Feedstock used in the composting experiment were source separated kitchen organic wastes (pre and post-consumer), corresponding to a daily service of approximately 500 meals, and grass clippings from the garden of the same company (Fig. 1b). Animal products, such as meat, dairy and fats, were also included. Pine wood shavings ( 1 to $5 \mathrm{~cm}$ diameter) were used as bulking agent. In each composter ( 3 replicates), the organic waste to the bulking agent ratio was $1.5: 1$ in a volume basis, or 3:1 in a wet weight basis. Composters were fed for 52 days (three waste batches a week), until each composter was complete. In order to assure a comparable feedstock, kitchen waste batches were fractionated in qualitative similar portions of $10 \mathrm{~L}$ before being incorporated into each composter (Table 1 ).

The total amount of waste to be treated by each composter was $338 \mathrm{~kg}( \pm 2.4)$ (wet weight basis), with an average incorporation 

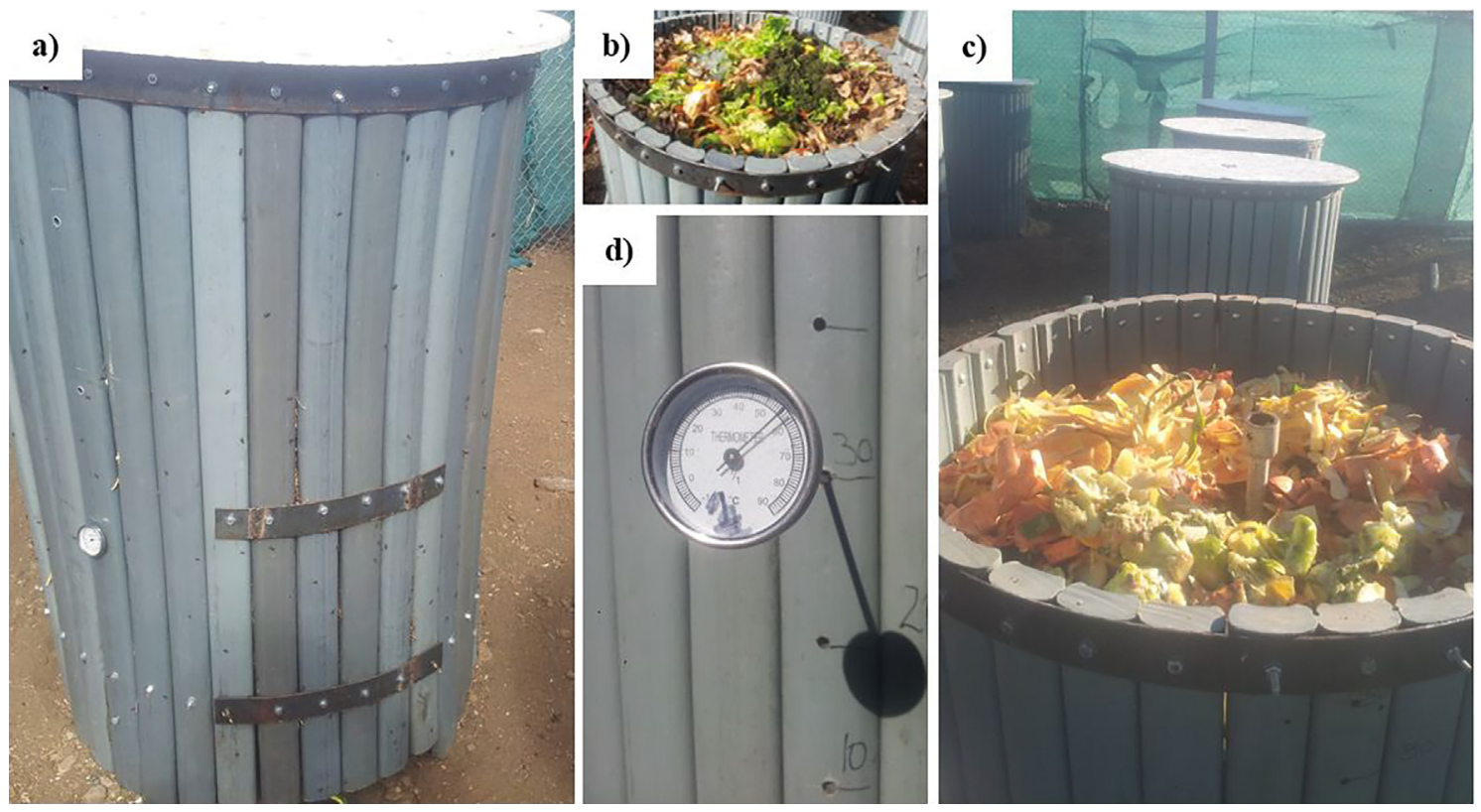

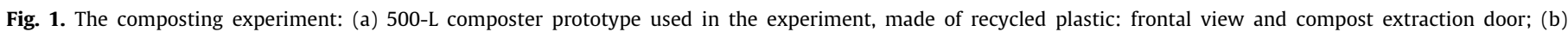

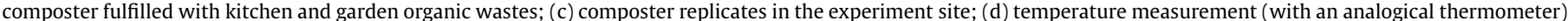
through holes perforated every $10 \mathrm{~cm}$ (height) in the recycled plastic tables of each composter prototype.

Table 1

Type and quantity (wet weight and volume) of organic wastes incorporated in the composters.

\begin{tabular}{|c|c|c|c|c|}
\hline & Wet weight $(\mathrm{kg})$ & Volume (L) & Specific weight $^{(\mathrm{b})}\left(\mathrm{kg} \mathrm{L}^{-1}\right)$ & $\%$ of the total weight \\
\hline Kitchen wastes & $246( \pm 1.5)$ & $583( \pm 2.2)$ & 0.42 & $73 \%$ \\
\hline Garden wastes & $15( \pm 0.4)$ & $50( \pm 1.0)$ & 0.30 & $4 \%$ \\
\hline Bulking agent $\mathrm{t}^{(\mathrm{a})}$ & $77( \pm 0.5)$ & $417( \pm 5.8)$ & 0.18 & $23 \%$ \\
\hline Total & $338( \pm 2.4)$ & $1050( \pm 9.0)$ & 0.32 & $100 \%$ \\
\hline
\end{tabular}

Waste mixture had a moisture content ranging from 50 to $70 \%$

Values are the means of three replicates (i.e. composter). SD is indicated in parenthesis.

(a) Pine wood shavings.

(b) Specific weight $\left(\mathrm{kg} \mathrm{L}^{-1}\right)=$ Wet weight $(\mathrm{kg})$ :Volume (L).

rate of $6.5 \mathrm{~kg} \mathrm{day}^{-1}$ or $0.68 \mathrm{~kg}$ per litre of the composter. Once the three composters were filled up, there was an initial reduction of the waste pile height from 100 to $80 \mathrm{~cm}$ (average). The "stratification effect" in the composting process was studied trough four predefined layers (or strata) along the waste pile or composter height. These layers corresponded to the following equivalent height ranges of the compost bin prototype, measured from the perforated plastic base: T10 $=0-20 \mathrm{~cm}$; T30 $=20-40 \mathrm{~cm}$, T50 $=40-60 \mathrm{~cm}$; and T70 $=60-80 \mathrm{~cm}$. For this research, each layer was established as a treatment (T10, T30, T50 and T70). Thus, obtaining an experimental design of four treatments with three replicates (composter) each.

\subsection{Temperature monitoring and sampling}

Using a stainless steel analogical thermometer, composting temperature was measured at the predefined "layers" of the composting mixture pile (i.e. in each treatment: T10, T30, T50 and T70) through holes perforated every $10 \mathrm{~cm}$ (in height) in the recycled plastic tables, and at 15 and $40 \mathrm{~cm}$ deep from the external perimeter of the compost bin, (Fig. 1d). Temperature measurements were made every two days, starting in the 10th day (when the waste pile was above $10 \mathrm{~cm}$ in height) until day number 93 from the first waste incorporation. Daily mean ambient temperature was also recorded automatically by a Davis Vantage Pro2 weather station.
At 103, 161, 203 and 244 days from the first organic waste incorporation (equivalent to 51, 109, 151 and 192 days from the last waste incorporation into each compost bin), one composite sample of the composting mixture (about $350 \mathrm{~g}$ ) made of 3 subsamples from each treatment (T10, T30, T50 and to T70: 0 to 20 $\mathrm{cm}, 20$ to $40 \mathrm{~cm}, 40$ to $60 \mathrm{~cm}$, and 60 to $80 \mathrm{~cm}$ from the composter height, respectively), were taken in each of the three composters (replicates) for laboratory analysis. Sampling was done with an Edelman type auger. A portion of fresh sample was separated and stored at $4{ }^{\circ} \mathrm{C}$ to measure $\mathrm{CO}_{2}$ evolution. Remaining sample portion was air-dried and milled for chemical analyses.

\subsection{Laboratory analysis}

All samples were analysed for the next variables and indicators: (i) microbial respiration, through $\mathrm{CO}_{2}$ evolution; (ii) water-soluble carbon (WSC); (iii) total organic carbon (TOC); (iv) total Kjeldahl nitrogen (TKN); (v) WSC: TKN ratio; (vi) TOC: TKN ratio); (vii) $\mathrm{pH}$; and (vii) electrical conductivity (EC).

Biological activity was evaluated through the microbial community respiration rate in controlled incubation conditions, through an adaptation of the technique for estimation of soil respiration using closed bottles. Released $\mathrm{CO}_{2}$ was trapped in a $\mathrm{NaOH}$ solution, precipitated as carbonates and indirectly determined by titration with $\mathrm{HCl}$ (Alef, 1995, Barrena Gómez et al., 2006; Tognetti et al., 2007a). Briefly, 15-20 g of fresh sample was 
weighed in $50 \mathrm{~mL}$ plastic centrifuge tubes, previously perforated to allow the release of $\mathrm{CO}_{2}$. In addition, a part of the sample was weighed and oven-dried to constant weight for gravimetric moisture content determination. Each perforated plastic tube (triplicate per sample) was placed in a $250 \mathrm{~mL}$ flask with $10 \mathrm{~mL}$ of $0.5 \mathrm{~N} \mathrm{NaOH}$ solution.

The flasks were hermetically sealed and incubated at $25^{\circ} \mathrm{C}$ for $72 \mathrm{~h}$. Three flasks without sample, but with the alkaline trap (0.5 N NaOH solution), were also incubated as controls. After the first $24 \mathrm{~h}$ of incubation, sodium carbonates were precipitated using 1-2 $\mathrm{mL}$ of a $3 \mathrm{~N} \mathrm{BaCl}_{2}$ solution. Subsequently, $\mathrm{NaOH}$ excess was measured by titration with $\mathrm{HCl} 0.25 \mathrm{~N}$. The quantification procedure was repeated at 48 and $72 \mathrm{~h}$ of incubation, after replenishing the alkaline trap solution. $\mathrm{CO}_{2}$ production rate $\left(\mathrm{mg} \mathrm{CO} \mathrm{Cg}^{-1}\right.$ dry matter $\mathrm{h}^{-1}$ ) was calculated from the average $\mathrm{CO}_{2}$ production of the last two days of incubation (Brewer and Sullivan, 2003; Hue and Liu, 1995).

Water-soluble carbon, electrical conductivity and $\mathrm{pH}$ were measured in samples aqueous extracts (1:10), obtained after $2 \mathrm{~h}$ of stirring and subsequent filtering by Whatman $\mathrm{N}^{\circ} 42$-filter type. WSC was determined as chemical oxygen demand, by the wet digestion method $\left(\mathrm{K}_{2} \mathrm{Cr}_{2} \mathrm{O}_{7}+\mathrm{H}_{2} \mathrm{SO}_{4}\right)$ and the subsequent spectrometric measurement of the reduced $\mathrm{Cr}$. Organic matter (OM) was determined by dry combustion at $550{ }^{\circ} \mathrm{C}$, and TOC was estimated as OM: 1.8. TKN was measured by the semi-micro Kjeldahl method (Laos et al., 2002; Rynk, 1992; Tognetti et al., 2007b).

\subsection{Statistical analysis}

In order to explore and find possible groupings in analysed variables and among performed treatments, a principal component analysis (PCA) was applied to standardized data sets. Comparisons between treatments means for each variable were done using
General Linear Models (GLM) of mixed effects. The differences between the specified effects were analysed by Fisher's LSD test, with a confidence limit $\geq 95 \%$. All analyses were performed with INFOSTAT v. 2015 software (Di Rienzo et al., 2011).

\section{Results and discussion}

\subsection{Composting temperature evolution}

Composting temperature is a variable that frequently presents good association with other stability indicators. In addition, it is the most used parameter to monitor and regulate the process, especially for pathogens control (Adhikari et al., 2012a; Laos et al., 2002; Smith and Jasim, 2009). Composting absolute maximum and minimum temperatures for each composter layer (treatments), and absolute maximum and minimum values of the whole compost bin (three replicates) were plotted versus time in Fig. 2.

The composting active phase lasted at least 50 days, considering absolute maximum temperatures $>40^{\circ} \mathrm{C}$ for the entire composter. Besides, absolute maximum temperatures exceeded sanitization parameter $\left(>55^{\circ} \mathrm{C}\right)$ for approximately 30 days, even when average ambient temperatures were around $11^{\circ} \mathrm{C}$. Nevertheless, minimum absolute temperatures never reached sanitization temperatures, considering the whole compost bin values. After 60-65 days, there was a drop in the composting temperatures reaching ambient values. This was possibly associated to the stabilization of the composting material (Laos et al., 2002; Sarika et al., 2014).

In $0-20 \mathrm{~cm}$ of the composter height (Fig. 2a), maximum temperatures were in the thermophilic range $\left(>40^{\circ} \mathrm{C}\right)$ for at least 20 days, and above the sanitization parameter $\left(55^{\circ} \mathrm{C}\right)$ for about 10 days. However, minimum temperatures never surpassed the sanitization temperature reference in this stratum. In the $20-40 \mathrm{~cm}$ layer (Fig. 2b), both maximum and minimum temperatures were

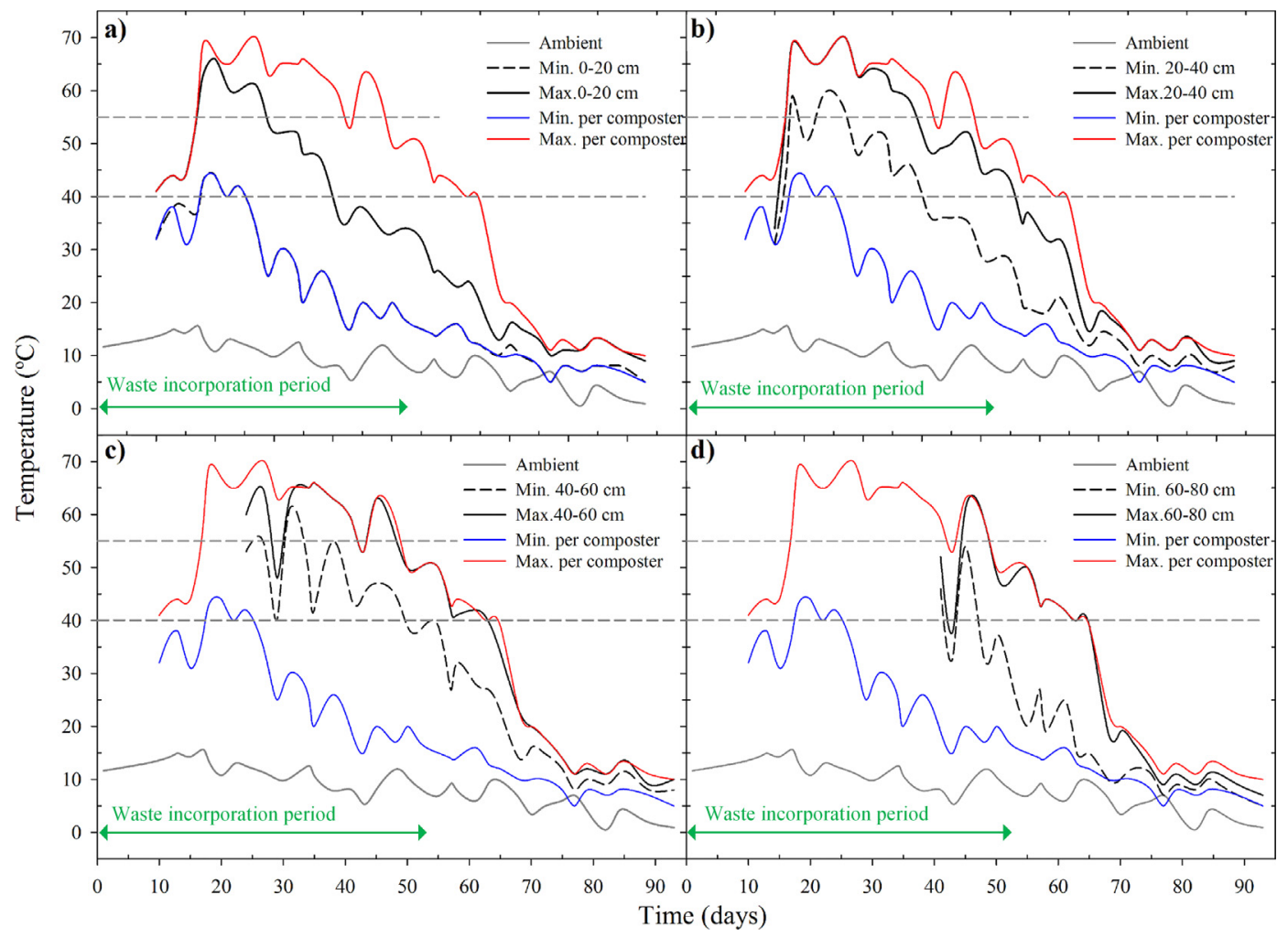

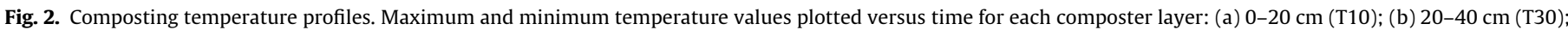

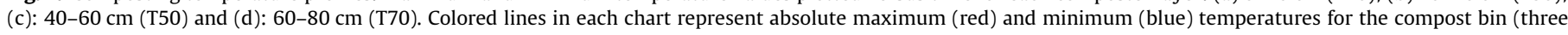

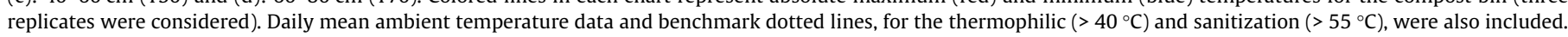


above $40{ }^{\circ} \mathrm{C}$ for at least 25 days and minimum temperatures were above sanitization temperatures for more than 5 days. In 40-60 $\mathrm{cm}$ of the composter height (Fig. 2c), maximum and minimum temperatures were hold in the thermophilic range for 25 to 30 days, and the minimum temperature values exceeded the sanitization reference for more than 3 days. Finally, the upper layer $(60-80 \mathrm{~cm})$ of the compost bin (Fig. $2 \mathrm{~d}$ ), showed temperatures above $40{ }^{\circ} \mathrm{C}$ for at least 20 days; however only maximum temperatures exceeded sanitization values for around 5 days in this stratum.

T30 and T50 layers showed the best thermal performance possibly not only due to adequate composting conditions (i.e. potential for self-heating), but also due to the insulating effect created by the upper (T70) and lower (T10) layers of material under process. In addition, heat conduction from the bottom section of the composter, could have contribute to the temperature rise in the intermediate layers. On the other hand, it could be presumed that the adjacent surface between the composting mass and the atmospheric air could have accentuated heat loss in the upper layer of the composting mass, despite of the composter lid. In T10 (0-20 $\mathrm{cm}$ of the composter height), other factors such as moisture excess or porosity conditions due to compaction, could have affected biological activity and the potential for self-heating (Adhikari et al., 2012a, 2012b; Iyengar and Bhave, 2006).

Described temperature profiles indicate that composting actively developed throughout the compost bins. However, only the intermediate layers of the composters (T30 and T50: 20 to $60 \mathrm{~cm}$ ) reached sanitization references, while in the bottom layer $(0-20 \mathrm{~cm})$ and in the top layer $(60-80 \mathrm{~cm})$ of the composters, the sanitization process was not successful. This suggests the need to carefully consider temperature average values (i.e. instead of the absolute minimum ones) as a reliable parameter to predict pathogen eradication in these systems, since sanitization requirements could not be reached in every sector of the composting mass, as it was previously observed in other decentralized composting experiences (Abdullah et al., 2013; Adhikari et al., 2012a, 2012b; Barrena et al., 2014; Storino et al., 2016a, 2016b).

These authors have observed a variable performance in relation to the evolution of the temperature at different depths of a compost bin. They conclude that this effect could be attributed to the frequency and quantity of each organic waste incorporation, the incorporation of meat, the presence of raw materials in the upper strata but not in the bottommost layers, and the design characteristics of the compost bins, among other aspects. Karnchanawong and Suriyanon (2011), observed that temperature decrease is associated to the moment when waste incorporation is discontinued in a household organic waste composting experience, using composters with different types of passive aeration. This study, and Smith and Jasim (2009), related the heat loss in small-scale compost bins to the thin layers of waste.
This scenario draws the attention to the influence of the waste incorporation rate, associated to the waste generation rate, in the process temperature evolution, thus, in the elimination of pathogens, weed seeds and bad smells. Also, it shows methodological divergences in the study of the small-scale composting process, which may require more specific standards for performance evaluation, since these "low-tech" systems differ from the "high-tech" in-vessel composters considered in PFRPs standards (USEPA, 2003).

For example, as an alternative to this standard, Storino et al. (2016a and 2016b), recalculated the number of thermophilic days (NTD) to consider the days that the temperature of the compost was higher than $45^{\circ} \mathrm{C}$. Also, these authors calculated the thermophilic heat sum (THS) as the sum of the daily differences between the temperature reached by the compost and the thermophilic threshold temperature $\left(45^{\circ} \mathrm{C}\right)$. On the other hand, it must be considered that new waste incorporations could introduce pathogens to the material that has already reached sanitization temperatures. This aspect should be included in the standards or normative that regulate small-scale composting systems.

The colored contour plot in Fig. 3 shows the evolution, and spatial distribution (in height), of the average temperatures of the three composters versus time. In order to calculate mean temperature values presented in this plot, the average of the measurements made at $15 \mathrm{~cm}$ and at $40 \mathrm{~cm}$ from the perimeter of the compost bin was first calculated every $10 \mathrm{~cm}$ of the composter height. Then, the average temperature value of the three composters was calculated. This figure contributes to a better understanding of this composter prototype thermal performance.

Within 15-70 cm of the composter height, sanitization temperatures lasted for 35 days. Particularly, between 30 and $40 \mathrm{~cm}$, the heat conservation allowed to keep very high composting temperatures $\left(60-70^{\circ} \mathrm{C}\right)$ for at least 7 days. Thus, the best thermal performance of the composter prototype appears to be between 20 and $50 \mathrm{~cm}$ of the composter height, confirming Rudé y Payró and Torres Castillo (2008) findings. These authors also observed a differentiated temperature evolution according to the composter height. In their study, sanitization temperatures were reached in upper layers, whereas the bottommost strata had the lowest relative temperatures, also possibly as a consequence of compaction or anaerobic conditions.

\subsection{Compost stability indicators and quality monitoring variables}

Considering temperature differentiated profiles throughout the composter layers, a multivariate analysis including the variables measured in the compost samples (WSC, evolution of $\mathrm{CO}_{2}, \mathrm{pH}$, EC, TKN, TOC, WSC: TKN and TOC: TKN ratios), was accomplished to explore the suspected stratification in the process along the composter height. Fig. 4 shows a Principal Components Analysis

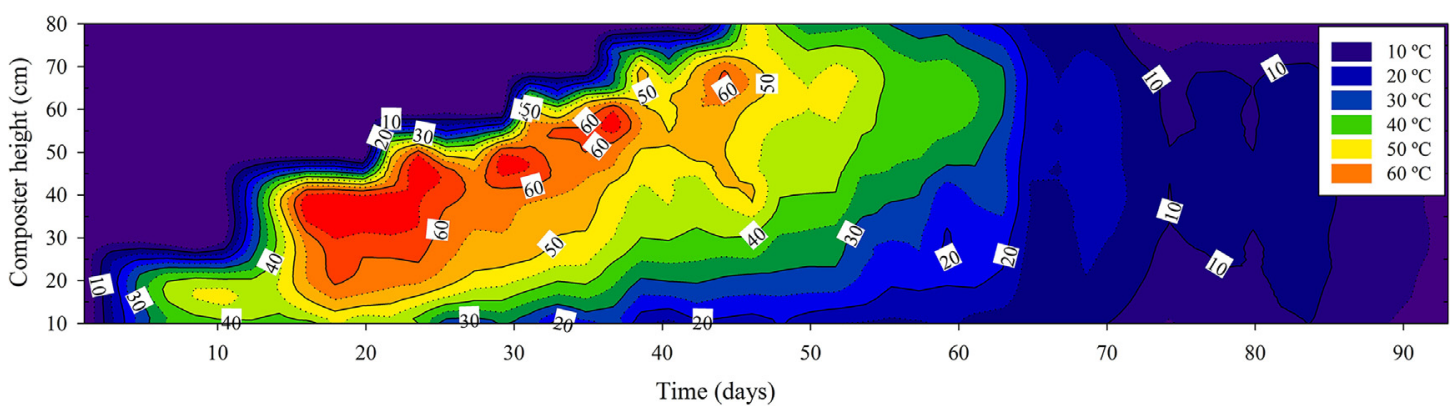

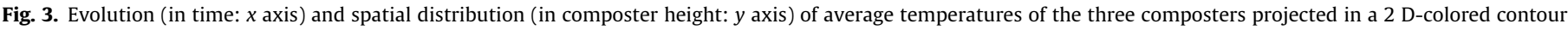
plot. Isolines correspond with temperature values $\left({ }^{\circ} \mathrm{C}\right)$ in $5^{\circ}$ ranges, from $10^{\circ} \mathrm{C}$ to $60^{\circ} \mathrm{C}$. 


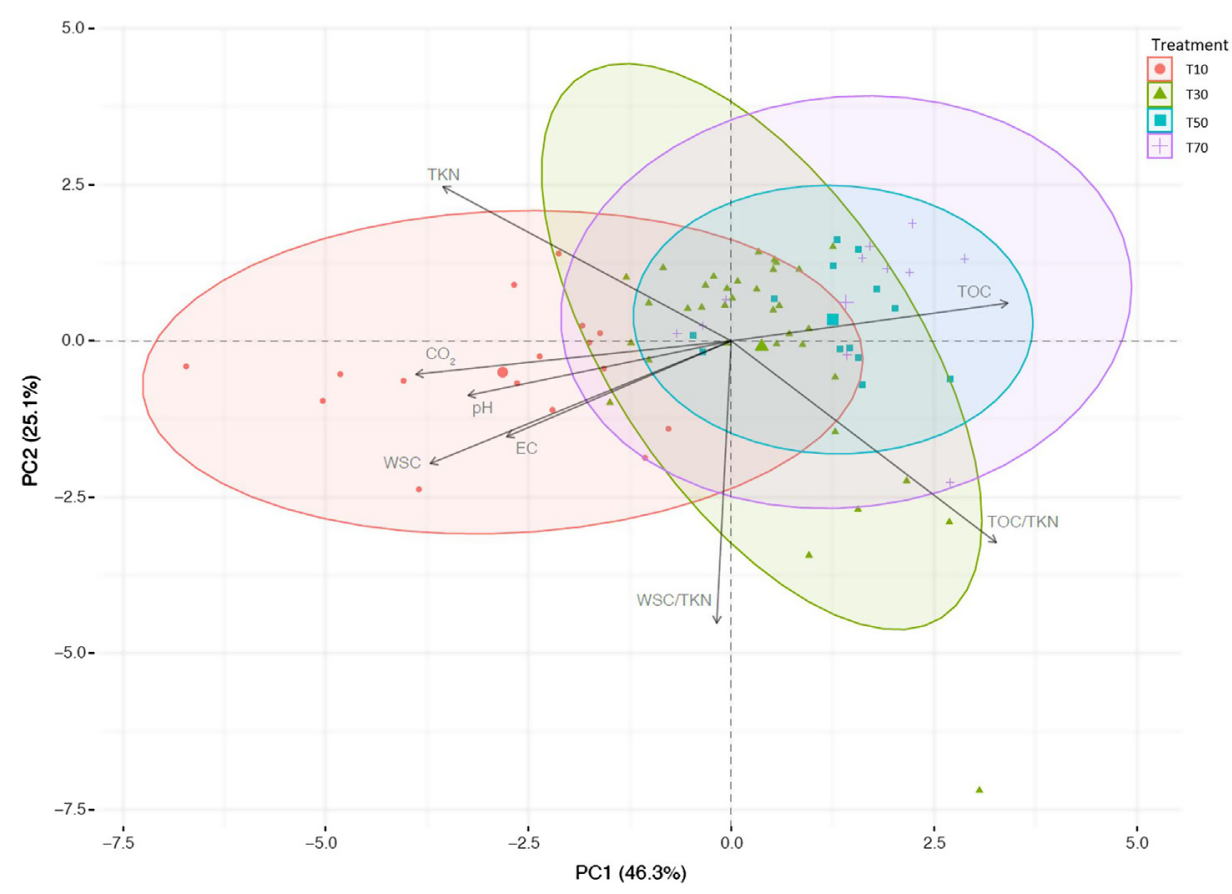

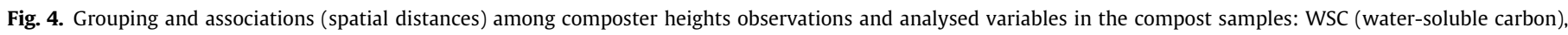

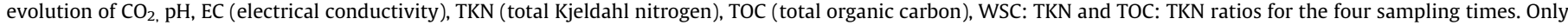
the two first principal components (PC 1 and PC 2) were plotted. PC1 explained $46.3 \%$ and PC 2 explained $25.1 \%$ of the total variability (PC1 + PC2 = 71.4\%).

(PCA) biplot, with the simultaneous representation of all observations and the variables measured in the compost samples (WSC, evolution of $\mathrm{CO}_{2}, \mathrm{pH}, \mathrm{EC}, \mathrm{TKN}, \mathrm{TOC}, \mathrm{WSC}$ : TKN and TOC: TKN ratios), for the four sampling times.

In the biplot, three differentiated groups of observations (T70 + T50, T30 and T10) are projected, suggesting a data grouping that may respond to a differentiated evolution of the composting process. Furthermore, T50 (40 to $60 \mathrm{~cm}$ composter layer) and T70 $(60-80 \mathrm{~cm})$ observations are mostly located on the opposite factorial plane from the T10 $(0-20 \mathrm{~cm})$ ones, whereas T30 $(20-40 \mathrm{~cm})$ results are projected between those groups.

Higher values for all variables, except for TOC and the TOC: TKN ratio, may be predicted for the 0 to $20 \mathrm{~cm}$ composter layer. On the other hand, both upper composter layers (T50 and T70) showed a similar behaviour among them, and lower values for stabilization variables (i.e. more stabilized compost) with respect to the intermediate (T30) and bottommost (T10) layers. Although, PCA is an exploratory and descriptive analysis, it shows preliminary a controversial tendency for small-scale composting, reflecting less evolution in the first $20 \mathrm{~cm}$ (T10) (i.e. the first incorporated waste) with respect to the upper 20 to $80 \mathrm{~cm}$ (more fresh feedstock) of the waste pile height (T70, T50 and T30).

In addition to the temperature evolution, compost stabilization was particularly studied in each composter layer (treatments), through these recommended indicators (Laos et al., 2002; Rynk, 1992; Tognetti et al., 2007a; Tognetti et al., 2007b): WSC (Fig. 5a), related to easily degradable carbon content; $\mathrm{CO}_{2}$ evolution (Fig. 5b), as a microbiological activity indicator; WSC: TKN (Fig. 5c) and TOC: TKN (Fig. 5d) ratios, in order to assess potential nitrogen deficiency or excess.

In this study, WSC values in T10, T50 and T70 treatments showed a general downward trend, ranging from $20.5 \mathrm{~g} \mathrm{~kg}^{-1}$ (T10 at 103 days from the first organic waste incorporation) to a minimum of $4.8 \mathrm{~g} \mathrm{~kg}^{-1}$ (T50 at 203 days) (Fig. 5a). In contrast, T30 WSC values remained stable around $10-15 \mathrm{~g} \mathrm{~kg}^{-1}$ throughout the sampling period. In the last sampling instance ( 244 days), WSC final values revealed two differentiated groups among treatments (Fisher LSD, $p<0.05$ ). T10 and T30 layers reached an average available carbon content of $13 \mathrm{~g} \mathrm{~kg}^{-1}$. On the other hand, T50 and T70 reached a WSC value of $5 \mathrm{~g} \mathrm{~kg}^{-1}$ at the end or the treatment. Several composting studies have suggested that a WSC content ranging from 4 to $17 \mathrm{~g} \mathrm{~kg}^{-1}$ could be taken as a reference for considering the compost as stable (Mazzarino et al., 2012; Tognetti et al., 2007a, 2007b). The differences found in WSC values between the upper layers (T50 and T70) and the lower layers (T10 and T30) of the composter, could point out leachates migration and absorption in the bottom area of the composter.

Leachates absorption in the bottom of the composter implies the accumulation and availability of easily degradable organic compounds in the bottommost stratum (T10). This may be associated with a greater biological activity, analysed in this study through the $\mathrm{CO}_{2}$ evolution measurement. In all composter strata, measured $\mathrm{CO}_{2}$ evolution also showed a downward trend throughout the sampling period as WSC content did. However, final $\mathrm{CO}_{2}$ values (samples taken at 244 days from the first waste incorporation) were $193,201,248 \mathrm{mg} \mathrm{CO} \mathrm{kg}^{-1} \mathrm{~h}^{-1}$ for T30, T70 and T50, respectively, whilst in $\mathrm{T} 10$ layer was $507 \mathrm{mg} \mathrm{CO}_{2} \mathrm{~kg}^{-1} \mathrm{~h}^{-1}$ (Fig. 5b). At 244 days of treatment, $\mathrm{CO}_{2}$ final values in the three upper layers of the composter (T30, T50 and T70) were around the maximum respiration rate suggested for a stabilized compost ( $\leq 200 \mathrm{mg} \mathrm{CO} \mathrm{kg}^{-1} \mathrm{~h}^{-1}$ ) (Mazzarino et al., 2012; Rynk, 1992; Tognetti et al., 2007a, 2007b). However, final respiration rate in T10 stratum doubled the maximum $\mathrm{CO}_{2}$ value suggested for a stable compost. Furthermore, T10 showed significantly higher (Fisher LSD, $p<0.05) \mathrm{CO}_{2}$ values than the rest of the strata at all sampling times.

A stable compost, with a low easy degradable carbon content, is expected to show decreased microbial respiration with respect to the active composting stage (Bernal et al., 2009). In the lower composter stratum, $\mathrm{CO}_{2}$ results indicated an extension of the compost stabilization time (see Fig. 2), in agreement with the WSC evolution in this layer. If draining conditions are not carefully considered 

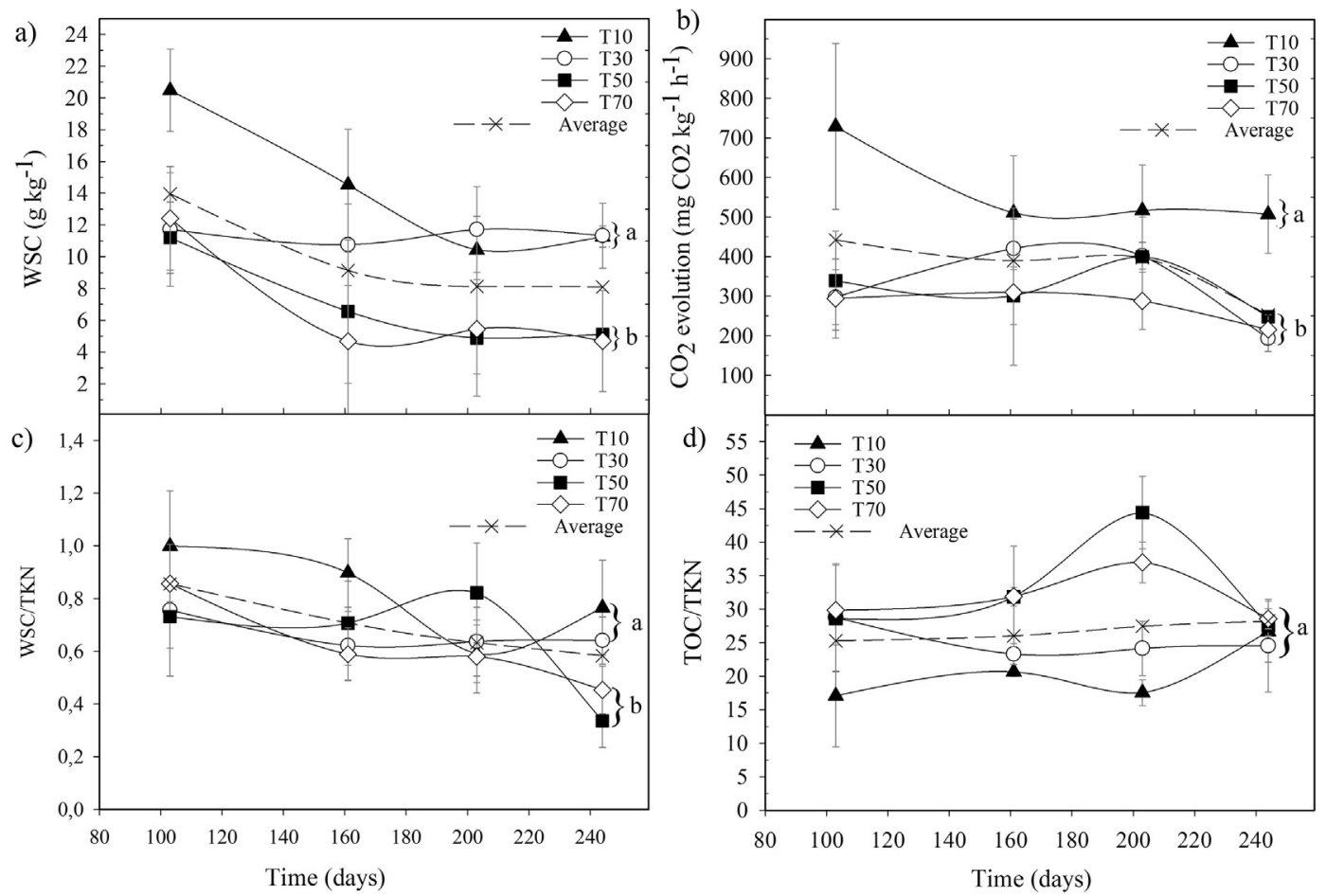

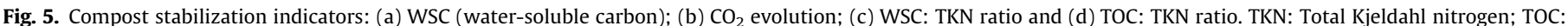

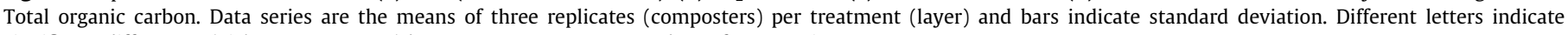
significant differences (Fisher LSD, $p<0.05$ ) between treatments at 244 days of composting.

in static composting systems, leachates accumulation in lower strata could imply a longer stabilization period due to extended easy degradable carbon availability and to the lack of oxygen.

The WSC: TKN ratio is also one of the most recommended indicators for compost stability assessment. This indicator reflects the lack of easy available carbon for microorganisms to growth despite $\mathrm{N}$ availability, giving an insight into the material stability degree. According to several authors, values of this indicator under 0.30.7 are recommended to consider a compost as stable (Hue and Liu, 1995; Mazzarino et al., 2012; Tognetti et al., 2007a, 2007b). In this study, average WSC: TKN ratio (for all strata) ranged from 0.58 to 0.86 during the sampling period (103 to 244 days of composting). At the end of the experiment, this ratio was about 0.30 , $0.34,0.78$ and 0.79 for $\mathrm{T} 50, \mathrm{~T} 70, \mathrm{~T} 30$ and $\mathrm{T} 10$, respectively (Fig. 5c), and two groups of treatments or layers could be recognized in relation to this stability indicator (Fisher LSD, $p<0.05$ ). On the one hand, T10 and T30 showed higher WSC: TKN ratios, being slightly above the stability recommended parameter range. On the other hand, both upper layers (T50 and T70) reached the reference WSC: TKN ratio values after 160 days of composting.

The C: $\mathrm{N}$ ratio (TOC: TKN ratio, in this study) has also been considered as a reference to assess compost stability, and it could be relevant to understand changes in the composting process. However, it is currently a controversial parameter and requires being complemented with other variables and indicators in order to evaluate the stability of a compost, as it is done in this study (Adhikari et al., 2012c; Karnchanawong and Suriyanon, 2011; Storino et al., 2016a, 2016b). Despite this considerations, other authors and environmental authorities have suggested a $\mathrm{C}$ : $\mathrm{N}$ ratio between 10 and 20 for defining compost stabilization (Mazzarino et al., 2012; Papadopoulos et al., 2009).

In final compost samples (taken at 244 days of composting), there were not significant differences in the C: $\mathrm{N}$ ratio between the composter layers, ranging from 24 to 29. In addition, there was not a downward trend on the average $\mathrm{C}$ : $\mathrm{N}$ values throughout the sampling period (103 to 244 days of composting) (Fig. 5d), as it would have been expected. Probably, if the monitoring of this parameter had been initiated earlier in the composting process, it may have shown a major variability. Also, it should be considered that the bulking material (pine wood shavings) in unsieved samples might have provided a TOC source that overlaps the typical or expected $\mathrm{C}$ : $\mathrm{N}$ ratio evolution.

Considering the average performance of the entire composter, including the $0-20 \mathrm{~cm}$ layer, it could be established an approximate period for the material stabilization according to some of the indicators studied. Temperature evolution indicates a stabilization period ending (when the composting mass temperature reaches ambient temperature) around 70-90 days from the first waste incorporation (see Fig. 2). Considering WSC and WSC: TKN ratio indicators, the compost stabilization period could be inferred between 155 and 160 days since the incorporation of waste into the composters started. This is equivalent to say 103 to 108 days since the end of feedstock incorporation into the composters (see Fig. $5 \mathrm{a}$ and $\mathrm{c}$ ). In contrast, according to the $\mathrm{CO}_{2}$ production, the compost was stable only after 240 days from the first waste incorporation, or around 188 days since the feedstock incorporation ended.

Given that $\mathrm{CO}_{2}$ evolution represent a biological variable and the sample heterogeneity, the outcomes of this technique could be less robust or reproducible than chemical parameters such as WSC or WSC: TKN ratio. Is that why these last parameters could be more reliable in order to determine the stability period of a material under composting. Nevertheless, differences in the stabilization period given by temperature, WSC, WSC: TKN ratio and $\mathrm{CO}_{2}$ evolution, collaborate to explain that the temperature evolution is not only related to biological and chemical variables, but also to physical variables (i.e. heat transfer and conservation).

Fig. 6 shows the evolution of pH (Fig. 6a), EC (Fig. 6b), TKN (Fig. 6c) and TOC (Fig. 6d), during the measuring period (from 103 to 244 days of composting) in each composter layer or 

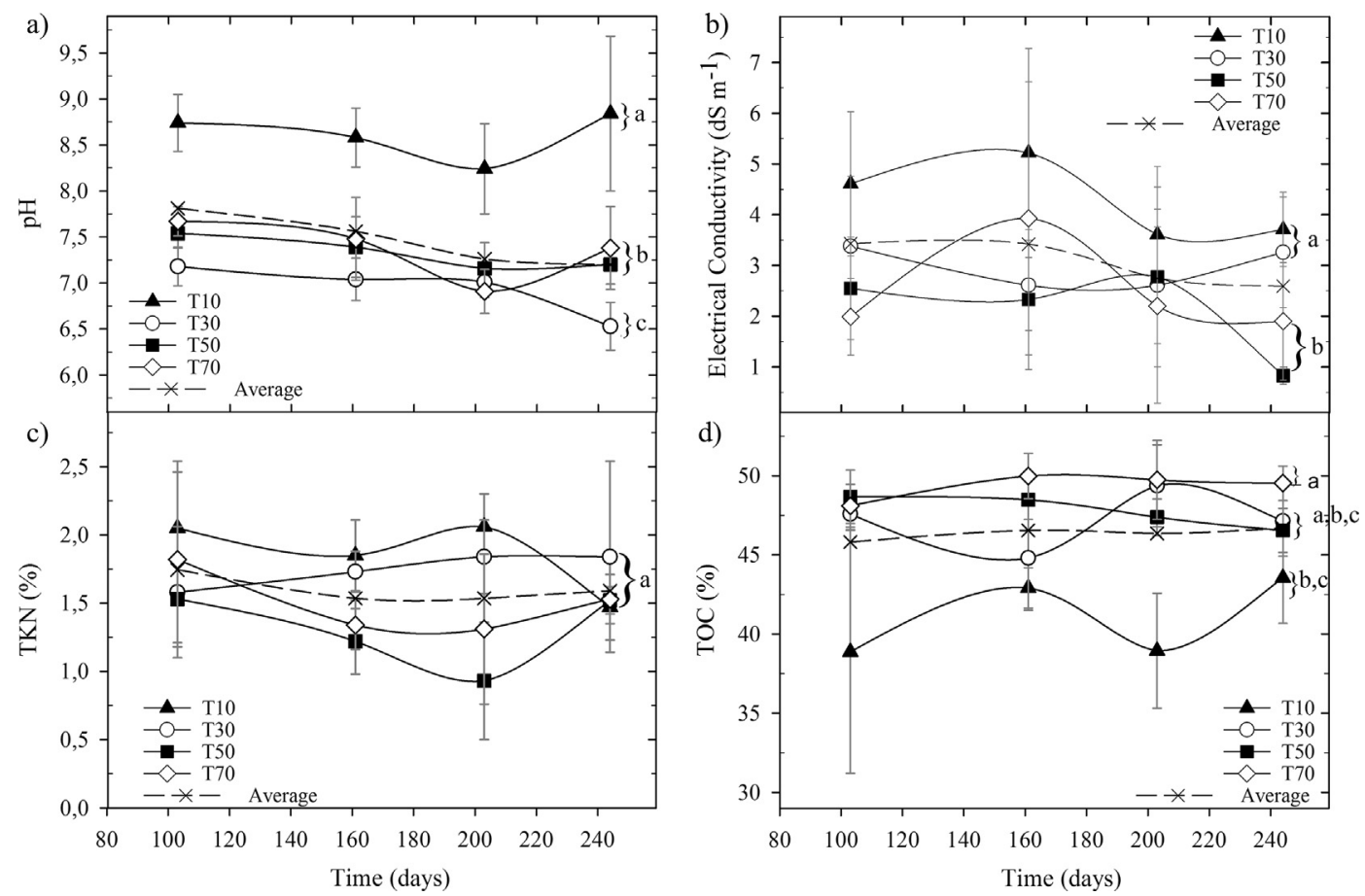

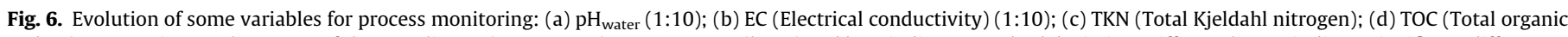

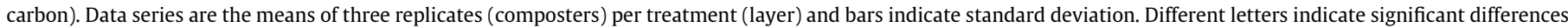
(Fisher LSD, $p<0.05$ ) between treatments at 244 days of composting.

treatment. These variables were measured for the process monitoring, in order to detect needed control actions, such as adjustment of type and quantity of feedstock or $\mathrm{pH}$ correction. Nevertheless, a profuse assessing of compost maturity and or quality is not intended in this study. $\mathrm{pH}$ mean values were significantly different throughout the composter after 244 days of composting (Fisher LSD, $p<0.05$ ) (Fig. 6a). Lowest pH corresponded to T30 (average $\mathrm{pH}$ : 6.5) followed by T70 and T50 (7.1 and 7.2, respectively). $\mathrm{pH}$ was higher in the bottom layer (T10) throughout the composting process and ended around 8.8. Taking into consideration these results, it could be predicted that compost obtained from T30, T50 and T70 would have a better final $\mathrm{pH}$ range for agricultural applications (recommended range: 6 to 7.8) (Laos et al., 2002; Mazzarino et al., 2012; Rynk, 1992) than compost from T10.

EC values were within $2.5-3.5 \mathrm{dS} \mathrm{m}^{-1}$ throughout the composter (all layers) (Fig. 6b), thus, soluble salts content in produced compost would agree with recommended values for most agronomic applications (Mazzarino et al., 2012). However, EC values in T30 and T10 samples were significantly different (Fisher LSD, $p<0.05$ ) from the upper layers (T70 and T50). In previous work, as well as in other authors experiences, elevated EC values were observed in compost made from dining wastes. This is associated to the presence of cellulosic material in the feedstock, such as napkins and tablecloths made with paper (Arrigoni et al., 2015; Faverial and Sierra, 2014; Kalamdhad and Kazmi, 2009a; Kalamdhad and Kazmi, 2009b). However, in this study, the differences in the EC values between the upper and the lower layers of the composter, also would show leachates accumulation in the lower part of the composter; leachates frequently include dissolved salts and, thus, increase compost electrical conductivity.

Total organic carbon (TOC) content is associated with the microbial activity, water holding capacity and nutrients release, among other effects, not only in the final product but also for the composting process evolution (Campitelli and Ceppi, 2008; Mazzarino and Satti, 2012). Nitrogen content is also a functional component for the composting process, because of its relevance for microbial reproduction and growth, beyond its importance in the final compost quality (Campitelli and Ceppi, 2008; Mazzarino and Satti, 2012). Average TOC and Total Kjeldahl Nitrogen (TKN) percentages showed slight variations during the composting process (Fig. 6c and d), and did not show significant differences in the last sampling time between the composter layers. Compost final TOC values were around 39\% and $45 \%$ and final TKN ranged from 1.6 to $1.8 \%$.

Considering that WSC values decreased at the end of the process (see Fig. 5a), pine wood shavings in unsieved samples could have contributed to compost $\mathrm{C}$ total content, as it was stated before and observed by Storino et al. (2016a and 2016b). Thus, it could be assumed that final compost TOC was mainly composed of this more stable $C$ source. This may be considered a positive compost quality feature, since carbon provided by organic amendments should not be easily attacked by microorganisms in order to prevent $\mathrm{N}$ immobilization (Campitelli and Ceppi, 2008; Tognetti et al. 2007a; Tognetti et al., 2007b). Average TKN content in final product were consistent with the characteristic values found in compost produced from kitchen wastes (Iyengar and Bhave, 2006; Kalamdhad et al., 2008; Smith and Jasim, 2009). However, according to this organic amendment intended use, a screening pre-treatment could be considered to increase the TKN availability in the obtained compost (Mazzarino and Satti, 2012; Smith and Jasim, 2009).

\section{Conclusions}

Our experiment results showed that small scale composting of kitchen and garden organic wastes is viable under unfavourable cold weather conditions. However, the process evolution was not homogenous throughout the compost bin. Most home composters commonly employ static systems (as compost bins), where the composting process evolves vertically. In these systems, it is usually accepted that the first batch of waste incorporated would have 
a higher stability degree than the upper and fresher waste strata. Our experience suggests that the organic matter transformation could not be associated to the order of the waste incorporations in a time line, as it could be expected. Instead, the first incorporated portions of waste needed a longer stabilization period, probably due to compaction and leachates accumulation in the lower layers of the composter. This outcome points out the need to discuss new forms of assessing and studying the composting process in vertical and static (without turning) compost bins, considering the observed stratification effect. Composters with a built-in mixing mechanism would be more effective in controlling excess of moisture and compaction aspects. However, construction costs may be impractical for community implementation of this systems. Thus, provided insights, could help to improve small-scale compost bin design for large-scale commercialization.

\section{Acknowledgements}

This research was funded by the Ministerio de Ciencia, Tecnología e Innovación Productiva, grant $\mathrm{N}^{\circ}$ PICT 083/2009 (Dr. Francisca Laos), and by the Universidad Nacional de Río Negro (Grant N PI UNRN 40-B149/2011-2013; Dr. Francisca Laos). Juan Pablo Arrigoni designed and carried out the field experiment and laboratory analysis, analyzed data and prepared the manuscript. Gabriela Paladino collaborated with sampling, laboratory analysis and preparing the manuscript. Lucas Garibaldi guided the statistical data analysis and cooperated with the experimental design and revising the manuscript. Francisca Laos supervised the experiment design and execution, and the results discussion, provided the financial support by means of the grants detailed above, and cooperated revising the manuscript.

We would like to thank to INVAP SE, for providing experimental site and other critical resources. Also, to PJA SRL Co., Luis Arceo Co., Dangen Plásticos Co. and TSB S.A for financial support and contribution with the composter prototypes construction. We are also grateful to Mr. Gabriel Russo for his valuable collaboration with the hard work and to Dr. Nestor Perez-Méndez for his help with graphs design.

\section{References}

Abdullah, N., Chin, N.L., Mokhtar, M.N., Taip, F.S., 2013. Effects of bulking agents load size or starter cultures in kitchen-waste composting. Int. J. Recycl. Org. Waste Agric. 2, 3. https://doi.org/10.1186/2251-7715-2-3.

Adhikari, B.K., Trémier, A., Martinez, J., Barrington, S., 2010. Home and community composting for on-site treatment of urban organic waste: perspective for Europe and Canada. Waste Manage. Res. 28, 1039-1053. https://doi.org $10.1177 / 0734242 \times 10373801$.

Adhikari, B.K., Tremier, A., Barrington, S., 2012c. Performance of five Montreal West Island home composters. Environ. Technol. 33 (21), 2383-2393.

Adhikari, B.K., Trémier, A., Martinez, J., 2012b. Home composting of organic waste part 2: effect of management practices. Int. J. Environ Tech. Manage 15, 438464.

Adhikari, B.K., Trémier, A., Martinez, J., 2012a. Home composting of organic waste part 1: effect of home composter design. Int. J. Environ Tech. Manage 15, 417 437.

Alef, K., 1995. Estimation of microbial activities. In: Alef, K., Nannipieri, P. (Eds.) Methods in Applied Soil Microbiology and Biochemistry. Academic Press, San Diego, USA, pp. 214-219.

Arrigoni, J.P., Paladino, G., Laos, F., 2015. Feasibility and performance evaluation of different low-tech composter prototypes. Int. J. Environ. Prot. 5, 1-8. https://doi. org/10.5963/IJEP0501001.

Barrena, R., Font, X., Gabarrell, X., Sánchez, A., 2014. Home composting versus industrial composting: Influence of composting system on compost quality with focus on compost stability. Waste Manage 34, 1109-1116. https://doi.org 10.1016/j.wasman.2014.02.008.

Barrena Gómez, R., Vázquez Lima, F., Sánchez Ferrer, A., 2006. The use of respiration indices in the composting process: a review. Waste Manage Res 24, 37-47.

Benjawan, L., Sihawong, S., Chayaprasert, W., Liamlaem, W., 2015. Composting of biodegradable organic waste from Thai household in a semi-continuous composter. Compost Sci. Util. 23, 11-17. https://doi.org/10.1080/ 1065657X.2014.963742.
Bernal, M.P., Alburquerque, J.A., Moral, R., 2009. Composting of animal manures and chemical criteria for compost maturity assessment A review. Bioresour. Technol. 100, 5444-5453. https://doi.org/10.1016/j.biortech.2008.11.027.

Brewer, L.J., Sullivan, D.M., 2003. Maturity and stability evaluation of composted yard trimmings. Compost Sci Util 2, 96-112.

Campitelli, P., Ceppi, S., 2008. Chemical, physical and biological compost and vermicompost characterization: A chemometric study. Chemometr. Intell. Lab. Syst. 90, 64-71.

Chan, Y.C., Sinha, R.K., Wang, Weijin, 2011. Emission of greenhouse gases from home aerobic composting, anaerobic digestion and vermicomposting of household wastes in Brisbane (Australia). Waste Manage. Res. 29, 540-548. https://doi.org/10.1177/0734242X10375587.

Colón, J., Martínez-Blanco, J., Gabarrell, X., Artola, A., Sánchez, A., Rieradevall, J., Font, X., 2010. Environmental assessment of home composting. Resour. Conserv. Recycl. 54, 893-904. https://doi.org/10.1016/j.resconrec.2010.01.008.

Di Rienzo, J.A., Casanoves, F., Balzarini, M.G., Gonzalez, L., Tablada, M., Robledo, C. W., 2011. Grupo InfosStat. Universidad Nacional de Córdoba, Argentina, FCA. http://www.infostat.com.ar.

Diaz, L.F., De Bertoldi, M., Bidlingmaier, W., Stentifor, E., 2007. Compost Science and Technology. Elsevier Science, Amsterdam, The Netherlands, p. 380.

Faverial, J., Sierra, J., 2014. Home composting of household biodegradable wastes under the tropical conditions of Guadeloupe (French Antilles). J. Clean. Prod. 83, 238-244. https://doi.org/10.1016/j.jclepro.2014.07.068.

Hue, N.V., Liu, J., 1995. Predicting compost stability. Compost. Sci. Util. 3, 8-15.

Iyengar, S.R., Bhave, P.P., 2006. In-vessel composting of household wastes. Waste Manage 26, 1070-1080.

Kalamdhad, A.S., Kazmi, A.A., 2009b. Rotary drum composting of different organic waste mixtures. Waste Manage. Res. 27, 129-137. https://doi.org/10.1177/ 0734242 X08091865.

Kalamdhad, A.S., Kazmi, A.A., 2009a. Effects of turning frequency on compost stability and some chemical characteristics in a rotary drum composter. Chemosphere 74, 1327-1334. https://doi.org/10.1016/j.chemosphere. 2008.11.058.

Kalamdhad, A.S., Pasha, M., Kazmi, A.A., 2008. Stability evaluation of compost by respiration techniques in a rotary drum composter. Resour. Conserv. Recycl. 52, 829-834. https://doi.org/10.1016/j.resconrec.2007.12.003.

Karnchanawong, S., Suriyanon, N., 2011. Household organic waste composting using bins with different types of passive aeration. Resour. Conserv. Recycl. 55, 548-553. https://doi.org/10.1016/j.resconrec.2011.01.006.

Laos, F., Mazzarino, M.J., Walter, I., Roselli, L., Satti, P., Moyano, S., 2002. Composting of fish offal and biosolids in northwestern Patagonia. Bioresour. Technol. 81, 179-186.

Lleó, T., Albacete, E., Barrena, R., Font, X., Artola, A., Sánchez, A., 2013. Home and vermicomposting as sustainable options for biowaste management. J. Clean. Prod. 47, 70-76. https://doi.org/10.1016/j.jclepro.2012.08.011.

Mazzarino M.J., Satti P., Roselli, L. 2012. Indicadores de estabilidad, madurez y calidad de compost, in: Compostaje en Argentina: Experiencias de producción, calidad y uso. In: Mazzarino M.J. y Satti P. (Eds.). Universidad Nacional de Río Negro - Orientación Gráfica Editora S.R.L. Bariloche, Argentina, pp 55-66.

Mazzarino, M.J., Satti, P. (Eds.), 2012. Compostaje en la Argentina: Experiencias de producción, calidad y uso, Universidad Nacional de Río Negro-Orientación Gráfica Editora, Bariloche, Argentina, p. 348.

Onwosi, C.O., Igbokwe, V.C., Odimba, J.N., Eke, I.E., Nwankwoala, M.O., Iroh, I.N., Ezeogu, L.I., 2017. Composting technology in waste stabilization: On the methods, challenges and future prospects. J. Environ. Manage. 190, 140-157. https://doi.org/10.1016/j.jenvman.2016.12.051.

Papadopoulos, A.E., Stylianou, M.A., Michalopoulos, C.P., Moustakas, K.G., Hapeshis, K.M., Vogiatzidaki, E.E.I. Loizidou, M.D., 2009. Performance of a new household composter during in-home testing. Waste Manage. 29, 204-213. https://doi. org/10.1016/j.wasman.2008.03.016.

Platt, B., McSweeney, J., Davis, J., 2014. Growing Local Fertility: a Guide To Community Composting 1-121.

Rudé y Payró, E., Torres Castillo, R., 2008. Evaluación de diferentes modelos de compostadores domésticos. Universidad de Barcelona, Barcelona, España, p. 23.

Rynk, R., 1992. On-Farm Composting Handbook. Northeast Regional Agricultural Engineering Service, Cooperative Extension Service. Ithaca, Nueva York, EEUU, p. 186.

Sánchez, A. Gabarrell, X., Artola, A., Barrena, R., Colón, J., Font, X, Komilis, D. 2015 Composting of Wastes. In: Mohammad, J., Taherzadeh, Tobias Richards (Ed.), Resources Recovery to Approach Zero Municipal Waste. CRC Press, p. 77-106. doi:10.1201/b18680-6

Sarika, D., Singh, J., Prasad, R., Vishan, I., Varma, V.S., Kalamdhad, A.S., 2014. Study of physico-chemical and biochemical parameters during rotary drum composting of water hyacinth. Int. J. Recycl. Org. Waste Agric. 3, 1-10. https://doi.org/ 10.1007/s40093-014-0063-1.

Smith, S.R., Jasim, S., 2009. Small-scale home composting of biodegradable household waste: overview of key results from a 3-year research programme in West London. Waste Manage. Res. 27, 941-950. https://doi.org/10.1177/ 0734242 X09103828.

Storino, F., Menéndez, S., Muro, J., Aparicio-Tejo, P.M., Irigoyen, I., 2016b. Effect of feeding regime on composting in bins. Compost. Sci. Util. 25, 71-81. https://doi. org/10.1080/1065657X.2016.1202794.

Storino, F., Arizmendiarrieta, J.S., Irigoyen, I., Muro, J., Aparicio-Tejo, P.M., 2016a. Meat waste as feedstock for home composting: Effects on the process and quality of compost. Waste Manage. 56, 53-62. https://doi.org/10.1016/j. wasman.2016.07.004. 
Varma, S.V., Kalamdhad, A.S., 2014. Stability and microbial community analysis during rotary drum composting of vegetable waste. Int. J. Recycl. Org. Waste Agric. 3. https://doi.org/10.1007/s40093-014-0052-4.

Tognetti, C., Mazzarino, M.J., Laos, F., 2007b. Cocomposting biosolids and municipal organic waste: effects of process management on stabilization and quality. Biol. Fertil. Soils 43, 387-397. https://doi.org/10.1007/s00374-0060164-8.
Tognetti, C., Mazzarino, M.J., Laos, F., 2007a. Improving the quality of municipal organic waste compost. Bioresour. Technol. 98, 1067-1076. https://doi.org/ 10.1016/j.biortech.2006.04.025.

USEPA, 2003. Environmental Regulations and Technology. Control of Pathogens and Vector Attraction in Sewage Sludge (under 40 CFR Part 503). United States Environmental Protection Agency, Office of Research and Development, Cincinnati, OH, USA. EPA/625/R-92/013. 186 pp. 